\title{
DEFORMATIONS AND VELOCITIES DURING THE COLD ROLLING OF ALUMINIUM ALLOYS
}

\author{
DEFORMACIJA IN HITROSTI PRI HLADNEM VALJANJU \\ ALUMINIJEVIH ZLITIN
}

\author{
Mitar Mišović ${ }^{1}$, Nebojša Tadić ${ }^{1}$, Milojica Jaćimović ${ }^{2}$, Mileta Janjić ${ }^{3}$ \\ ${ }^{1}$ University of Montenegro, Faculty of Metallurgy and Technology, Džordža Vašingtona bb, 81000 Podgorica, Montenegro \\ ${ }^{2}$ University of Montenegro, Faculty of Natural Sciences and Mathematics, Džordža Vašingtona bb, 81000 Podgorica, Montenegro \\ ${ }^{3}$ University of Montenegro, Faculty of Mechanical Engineering, Džordža Vašingtona bb, 81000 Podgorica, Montenegro \\ mitarm@ac.me \\ Prejem rokopisa - received: 2014-10-02; sprejem za objavo - accepted for publication: 2015-01-20
}

This paper presents the analysis results of investigations on the deformations and velocities during the cold rolling of strips of aluminium alloys AW2024 and AW5083 obtained with an application of the finite-element method (FEM) and the conventional rolling theory. The results of the simulation obtained using the FEM software DEFORM-2D were analysed for the displacements, effective strain and velocity of rolling. The diagrams of the changes in these values along the deformation zone were presented together with the identified characteristics of the trajectories of the surface and axis as the boundary surfaces for simulating the cold rolling of the strips. The finite effective strains were compared with the degree of reduction of the strip thickness, and equations were derived for the dependence of their ratio on the starting thickness of a strip. The equations for the dependence of the velocity of a strip and the roll ratio on the degree of reduction due to the control of forward and backward slips were also derived. The reliability of the obtained results and derived equations was tested with experimental tests, theoretical relationships for plane strain and the results for the forward slip published in the literature.

Keywords: cold rolling, FEM, displacements, effective strain, forward slip

Članek predstavlja analizo rezultatov preiskav deformacije in hitrosti pri hladnem valjanju trakov aluminijevih zlitin AW2024 in AW5083, dobljenih z uporabo metode končnih elementov (FEM) in konvencionalne teorije valjanja. Analizirani so bili rezultati simulacije, dobljene s FEM programsko opremo DEFORM-2D, za raztezek, efektivno obremenitev in hitrost valjanja. Predstavljeni so diagrami sprememb teh vrednosti vzdolž deformacijske cone, skupaj z identifikacijo značilnosti trajektorij površine in osi, kot mejnih površin za simulacijo hladnega valjanja trakov. Končne efektivne obremenitve so bile primerjane s stopnjo redukcije debeline trakov in razvite so bile enačbe za odvisnost njihovega razmerja od začetne debeline traku. Razvite so tudi enačbe za odvisnost hitrosti traku in razmerja valjev na stopnjo redukcije zaradi kontrole prehitevanja in zaostajanja traku. Zanesljivost dobljenih rezultatov in razvitih enačb je bila preizkušena s preizkusom, s teoretičnimi odvisnostmi za ravninsko napetost in za rezultate prehitevanja, objavljenega v literaturi.

Ključne besede: hladno valjanje, FEM, raztezek, efektivna obremenitev, prednji zdrs

\section{INTRODUCTION}

Cold rolling is the primary technological process for the preparation of strips, thin strips and foils of aluminium and its alloys. This process is applied for strips with thicknesses of up to $4 \mathrm{~mm}$, although strips with larger thicknesses can be rolled as well.

The cold-rolling technology has been constantly developed and improved with the intent to establish reliable quality and high productivity ${ }^{1,2}$. Regardless of the continuous development in all the areas, theoretical models of the process are still the subjects of a comprehensive research ${ }^{3,4}$. The understanding and control of deformation, kinematics and stress states are particularly complex due to the conditions for a reliable planning and control of the process ${ }^{5-7}$. The conventional theory of rolling ${ }^{8,9}$, the experimental procedures for tracing the measurement weights ${ }^{10-12}$ and the procedures for the FEM simulation ${ }^{4,13,14}$ were used in the research.

This paper reports experimental results for cold strip rolling and characteristic results for deformations and velocities obtained via FEM. A connection and comparison of the results obtained from different research procedures are discussed as well.

Strips made of alloys AW2024 and AW5083 with thicknesses from 4 to $0.6 \mathrm{~mm}$ were chosen for this research. These two alloys are widely used in all areas of metal material application and are also characterised by a wide range of final mechanical properties.

The analysis of the cold rolling of strips, thin strips and foils is based on the condition that it is a process with plane strain. In this manner, the geometry of the deformation zone and the change in the velocity of a strip and roll can be described using the scheme shown in Figure 1.

For the plane strain, the change in the width can be neglected $\left(b_{0}=b_{1}\right)$, and thus the deformations and geometric criteria for the dimensions of a strip and deformation zone can be described with the relationships:

$$
\begin{gathered}
\varphi_{h}=\ln \left(h_{0} / h_{1}\right), \varphi_{l}=\ln \left(l_{1} / l_{0}\right), \varphi_{\mathrm{b}}=\ln \left(b_{1} / b_{0}\right)=0 ; \\
\varphi_{h}=-\varphi_{l} ; b_{0} / h_{0} \geq 10 ;\left(l_{\mathrm{d}} / h_{\mathrm{m}}\right)_{\min }=2-3
\end{gathered}
$$


The length of the deformation zone $\left(l_{\mathrm{d}}\right)$ for absolutely solid rolls is calculated using the following equation:

$$
l_{\mathrm{d}}=\sqrt{R \Delta h-(\Delta h / 2)^{2}} \approx \sqrt{R \Delta h}
$$

However, a high value of the contact stress (the roll pressure) for cold rolling causes an elastic deformation of the roll with a radial compression (roll flattening). Thus, the length of the deformation zone increases (Figure 1) and can be calculated using the following equation:

$$
l_{\mathrm{de}}=x_{0}+x_{1}=x_{0}+\sqrt{R \Delta h+x_{0}^{2}}
$$

The value of $x_{0}$ is determined using the Hertz equation:

$$
x_{0}=\frac{8\left(1-v^{2}\right)}{\pi \cdot E} R P_{\mathrm{a}}
$$

where $v$ - Poisson's ratio, $E$ - the modulus of elasticity of the roll material, and $P_{\mathrm{a}}$ - the average roll pressure.

The movements of a strip at the entrance of the roll gap occur under the action of an active tangential friction force between the rolls and the strip. The horizontal velocity of the strip $\left(V_{\mathrm{s} x}\right)$ is determined using the horizontal velocity of the roll $\left(V_{\mathrm{r} x}\right)$. These velocities are

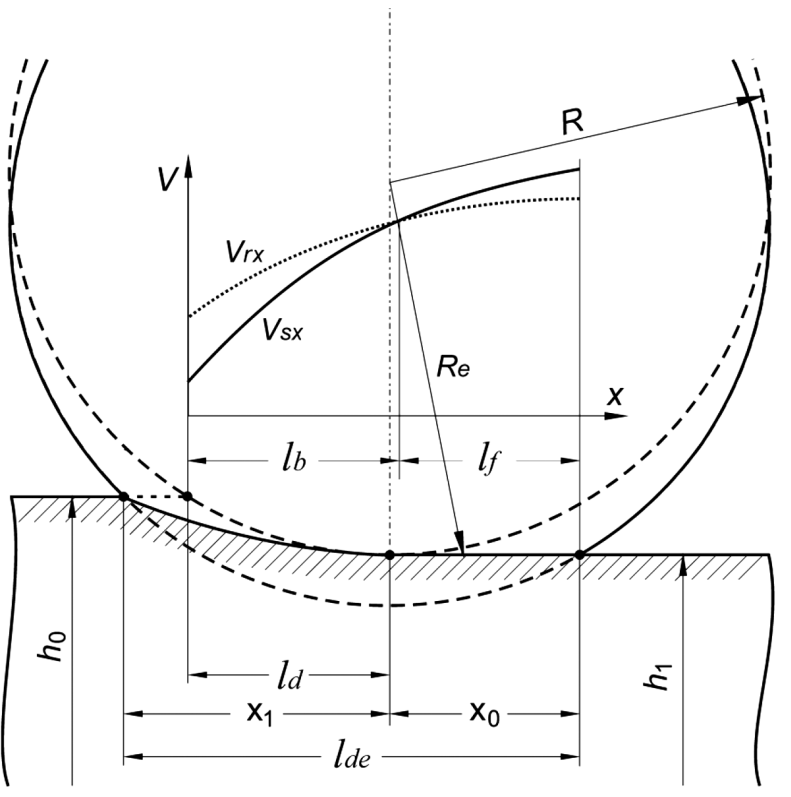

Figure 1: Deformation-zone geometry with and without an elastic deformation of rolls: $h_{0}, b_{0}, l_{0} / h_{1}, b_{1}, l_{1}$ - thickness, width and length of the initial/rolled strip, respectively; $l_{\mathrm{d}}, l_{\mathrm{de}}-$ length of deformation zone (contact between strip and roll) with and without an elastic deformation of rolls; $l_{\mathrm{b}}, l_{\mathrm{f}}-$ length of backward and forward slip zones; $R$ - roll radius; $R_{\mathrm{e}}$ - radius of an elastically deformed roll; $\Delta h=$ $h_{0}-h_{1}-$ absolute strip thickness reduction; $h_{\mathrm{m}}$ - mean strip thickness, i.e., $\left(h_{0}+h_{1}\right) / 2 ; V_{\mathrm{s} x}, V_{\mathrm{r} x}$ - horizontal velocities of strip and roll

Slika 1: Geometrija področja deformacije $z$ in brez elastične deformacije valjev: $h_{0}, b_{0}, l_{0} / h_{1}, b_{1}, l_{1}$ - debelina, širina in dolžina začetnega oziroma valjanega traku; $l_{\mathrm{d}}, l_{\mathrm{de}}-$ dolžina področja deformacije (stik med trakom in valjem) $\mathrm{z}$ in brez elastične deformacije valjev; $l_{\mathrm{b}}, l_{\mathrm{f}}-$ dolžina področja zaostajanja in prehitevanja; $R$ - premer valja; $R_{\mathrm{e}}$ - premer elastično deformiranega valja; $\Delta h=h_{0}-h_{1}-$ absolutno zmanjšanje debeline traku; $h_{\mathrm{m}}$ - povprečna debelina traku, to je $\left(h_{0}+h_{1}\right) / 2 ; V_{\mathrm{s} x}, V_{\mathrm{r} x}-$ horizontalna hitrost traku in valja

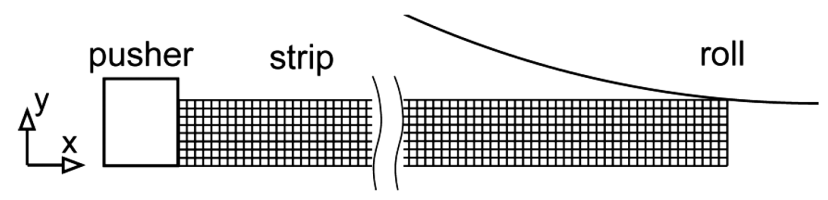

Figure 2: Scheme of 2D-FEM simulation of the rolling process Slika 2: Shema 2D-FEM simulacije postopka valjanja

altered along the deformation zone, thus creating a zone of the backward slip $\left(l_{\mathrm{b}}\right)$ in which the friction force is active and the relationship of the velocities is described as $V_{\mathrm{s} x}<V_{\mathrm{r} x}$, and a forward-slip zone $\left(l_{\mathrm{f}}\right)$ in which the friction force is reactive and the relationship of the velocities is described as $V_{\mathrm{s} x}>V_{\mathrm{r} x}$ (Figure 1). The relative difference in the velocity $\left(V_{\mathrm{s} x}-V_{\mathrm{r} x}\right) / V_{\mathrm{r} x}$ in zone $l_{\mathrm{b}}$ is known as the backward slip, and in zone $l_{\mathrm{f}}$, it is known as the forward slip. The forward and backward slips of a strip represent significant and carefully researched weights of the kinematics of the rolling process ${ }^{4,15-17}$.

A simulation of the rolling process for plane strain can be accomplished using the $2 \mathrm{D}$ method of finite elements. The scheme of the process simulation is presented in Figure 2.

As cold rolling is symmetrical to the longitudinal $x$-axis, it is sufficient to present the top half of a strip thickness and the top roll for a 2D simulation. The lower symmetrical portion of the strip and the lower roll can be neglected by setting the boundary condition in such a way that the displacement velocity in the $y$-axis direction is equal to zero on the longitudinal $x$-axis. In addition, when the friction force cannot accomplish the grasping of a strip by the rolls, it is necessary to use pushers, keeping in mind that the active friction force has a limited value and the pushing force is also limited. The movement velocity of a pusher is smaller than the velocity of the movement of a strip $\left(0.1 V_{s x}\right)$ and, therefore this force acts only while the rolls grasp the strip.

\section{EXPERIMENTAL DETAILS AND THE FEM SIMULATION}

\subsection{Rolling process}

The laboratory rolling of this work was carried out to assess the plane strain, the tolerance of dimensions, and the strain hardening of the alloys. Alloys AW2024 and AW5083 were examined. The final properties of the alloys can be obtained via different processes of thermal treatment ( $\mathrm{T}$ conditions) and mechanical treatment (H conditions). Alloy AW2024 can be thermally hardened so that its final mechanical properties are obtained through the thermal precipitation, whereas alloy AW5083 cannot be thermally hardened and its final mechanical properties are accomplished through strain hardening or annealing.

The initial 2024-alloy strips for the experimental rolling were industrially rolled to a thickness of $5 \pm 0.01$ $\mathrm{mm}$ and, subsequently, soft annealed (the T0 condition) and rolled. The modes of rolling and annealing for the 
M. MIŠOVIĆ et al.: DEFORMATIONS AND VELOCITIES DURING THE COLD ROLLING OF ALUMINIUM ALLOYS

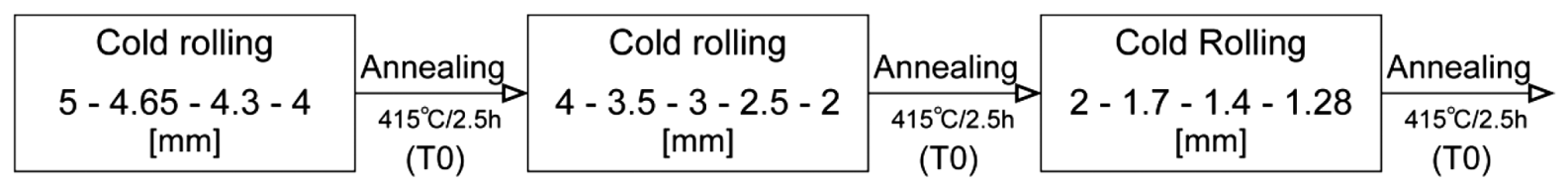

Figure 3: Modes of cold rolling/annealing of alloy-2024 strips

Slika 3: Načini hladnega valjanja/žarjenja trakov iz zlitine 2024

preparation of strips with thicknesses of 4, 2 and 1.28 $\mathrm{mm}$ are shown in Figure 3. The initial thickness of the 5083-T0 alloy strips is $1.28 \pm 0.01 \mathrm{~mm}$. The choice of dimensions and reductions was intended to ensure the conditions corresponding to the plane strain. The highest values of the reduction for all the strip thicknesses correspond to the conditions of the maximum bite on the laboratory rolling mill.

The rolling was completed on a laboratory duo rolling mill having rolls with a diameter of $125 \mathrm{~mm}$ and a peripheral velocity of $V_{\mathrm{r}}=173.4 \mathrm{~mm} / \mathrm{s}$. The lubrication of the strip and rolls was carried out with hydraulic oil. All the testing processes were completed without the use of tension on the strips.

The annealing was completed in a laboratory furnace with a temperature regulation accuracy of $\pm 2{ }^{\circ} \mathrm{C}$.

\subsection{FEM simulation of the rolling process}

\subsubsection{Software and mathematical formulation of tasks}

The commercial DEFORM-2D software was chosen for the simulation of the planned program of cold strip rolling under the conditions of plane strain. The DEFORM formulation of FEM for the mechanics of a rigid-plastic body is based on the known principle of the minimum virtual work expressed via the functional balance between the external and internal forces ${ }^{18,19}$ :

$$
\pi=\int_{V} \dot{\sigma \varepsilon} \mathrm{d} V+\int_{V} \lambda \dot{\varepsilon}{ }_{v} \mathrm{~d} V-\int_{S} F_{i} v_{i} \mathrm{~d} S
$$

where $\bar{\sigma}-$ the equivalent or effective stress (equal to yield stress $K_{\mathrm{f}}$ ), $\dot{\bar{\varepsilon}}$ - the equivalent or effective strain rate (determined on the basis of the components of the velocity of deformation for the plane strain), $\lambda-$ the Lagrange multiplier (equal to the mean stress), $\dot{\varepsilon}_{v}-$ the volumetric strain rate, $F_{\mathrm{i}}$ - the surface traction (for the processes with slip friction, this represents the friction force at the strip/roll contact determined with the normal rolling force and the friction coefficient) and $v_{\mathrm{i}}-$ the velocity (the slipping velocity of a strip on the roll surface).

The first term in Equation (5) refers to the deformational work, the second term expresses the condition of incompressibility and the third term refers to the impact of the friction forces on the strip/roll contact surface.

The Newton-Raphson iterative method is used by DEFORM to find solutions. This method is recommended for the majority of problems because it usually converges, using fewer iterations than the other methods ${ }^{19}$. All the simulations were completed with a strip as a rigid-plastic, deformable body hardened by the deformation, based on experimentally determined equations and with the rolls elastically deformed to a diameter determined with the Hitchcock formula.

\subsubsection{Choice of the finite-element mesh}

The finite-element mesh provides important baseline data for the analysis of strains, kinematics, and stress values. The choice of the shape and number of finite elements influences the calculation and the accuracy of the solutions for the analysed values. Square isoparametric finite elements represent a simple shape and are adequate for a simulation of the plane-strain process ${ }^{18,20}$. For cold rolling of strips, the geometry of the deformation zone takes on a simple shape. If square elements are chosen in a manner proportional to the strip thickness, the results for the strips with different thicknesses and under different conditions of reductions can be easily compared. The square isoparametric shape was chosen for these reasons.

The choice of the number of elements, i.e., the mesh density, should enable the required accuracy and convergence of the solutions. Based on the recommendations for the number of finite elements relative to the thickness, the checks for a mesh of 4 to 20 elements on half of a strip thickness were carried out for the simulation of plane strain in thin elements ${ }^{19}$. The changes in the shape of the displacement along the $x$ and $y$ axes were analysed depending on the number of finite elements. The displacements represent particularly important values because the strains, velocities and stresses are calculated on the basis of these values. For the sake of clarity, the displacement diagram was considered in a simplified form with two characteristic lines (trajectories) of nodes corresponding to the boundary surfaces of a strip: the line of contact between the metal and roll (the strip surface) and the horizontal centreline (the longitudinal axis of the strip). Since the characteristics of the displacement diagrams change slightly if the number of finite elements (FE) increases above 8, the complete further analysis was carried out with a mesh of eight finite elements on a half strip thickness (the shape of the displacement diagram is analysed in additional detail in Section 3.3.1).

\subsubsection{Choice of the coefficient of friction}

The choice of the contact-friction condition holds special importance for the cold-rolling process. A quantitative indicator of the friction conditions in plastomechanics is the contact-friction coefficient $(f)$. A functional analysis of the friction conditions is thus considered with respect to the change in the value of this coefficient. The simulation and analysis of the process 
can be carried out on the basis of a constant value for the friction coefficient. In this research, the simulation was carried out with an adopted value for the friction coefficient based on Coulomb's law. The coefficient of friction was varied in a range of $f=0.06-0.2$ for the purpose of performing this check $^{4,21}$. In the choice of the values of the friction coefficient, an analysis of the displacement diagrams was carried out in a manner similar to that of the choice of the finite-element mesh. The changes in the diagrams of displacements for different values of the friction coefficient from the extracted interval are evident and expected, but these values are not expressed to the extent of a reliable quantification along the complete deformation zone. Therefore, for further research on deformations and velocities, the presented results are given for the friction-coefficient value of $f=0.1$, which is often used for simulating similar rolling conditions ${ }^{22,23}$.

\section{RESULTS AND DISCUSSION}

\subsection{Dimensions and deformation coefficients of rolled strips}

The dimensions of the strips, the thickness reductions, the thickness tolerances $( \pm \delta h)$ and the spread $\left(\varepsilon_{\mathrm{b}}\right)$ of the experimental rolling were determined. The thickness tolerances of the rolled strips $( \pm \delta h)$ met the production standards for the given thicknesses and reductions of the tested alloys ${ }^{24}$.

The experimentally verified value of the spread $\left(\varepsilon_{\mathrm{b}}\right)$ was less than $2 \%$, which satisfied the condition for plane strain $^{25,26}$.

\subsection{Strain hardening of the alloys}

The strain hardening of the alloys was examined via tensile testing of standard specimens. The values of the yield stress $\left(K_{\mathrm{f}}\right)$, which depend on the degree of deformation by elongation $\left(\varphi_{1}\right)$ and the coefficient $(K)$ and the index $(n)$ of strain hardening were determined according to Hollomon's equation $K_{\mathrm{f}}=K \varphi_{1}$. Hollomon's equation was chosen because it describes the area of plastic deformation with a satisfactory accuracy. The beginning of the interval corresponds to the conventional yield strength $\left(R_{\mathrm{p} 0.2}\right)$. The boundary values of the uniform deformation intervals of the method of the tensile testing by elongation are limited.

In the area of high deformation degree, the data can be extrapolated but cannot be experimentally verified using the tensile-testing method. For this reason, the strain-hardening testing was carried out within the striprolling process. The strips with the same initial dimensions in the thermal state (T0) were rolled with different thickness reductions. After the rolling, specimens for the tensile testing were prepared from the strips, and the yield strength $R_{\mathrm{p} 0.2}$ was determined. The degree of deformation for the rolled strips was calculated on the basis of the strip thickness change $\left(\varphi_{\mathrm{h}}\right.$ in Equation (1)). The results for the standard deviation prove that Hollomon's equation $K_{\mathrm{f}}=f\left(\varphi_{\mathrm{h}}\right)$ fully applies to the strain hardening in the area of high deformation degrees.

Thus, for the FEM simulation of rolling, the chosen alloys are considered as the rigid-plastic materials that can be hardened in the deformational sense according to Hollomon's equation.

\subsection{Deformations}

\subsubsection{Displacements}

Displacement diagrams ( $\Delta x$ and $\Delta y$ ) for a $4-\mathrm{mm}$ thick strip and the singled-out trajectories of the surface and axes of the strip are presented in Figure 4. The points at the entrance and exit of the deformation zone were chosen according to the positions that are located outside the boundary values of the displacements. The displacements relative to the geometrical length of the deformation zone determined by Equation (3) are also traced in this analysis.

The change in the horizontal $\Delta x$-displacements shows the presence of characteristic areas and different mutual relationships of the boundary surfaces (Figure 4a). Area I is located at the entrance of the roll gap. The deformation begins on the surface, before the geometric entrance into the roll gap. The deformation is non-uni-
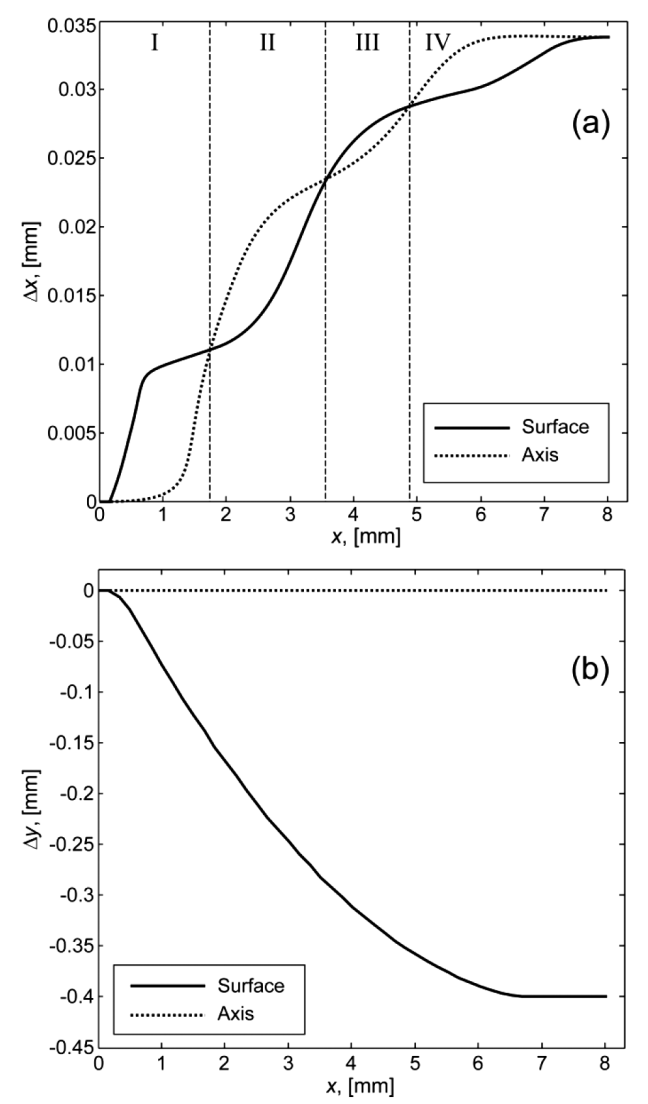

Figure 4: Displacements of mesh nodes in the directions of: a) $x$-axis and b) $y$-axis for reduction $\varepsilon=20 \%$ (alloy 2024, $h_{0}=4 \mathrm{~mm}, 8 \mathrm{FE}, f=$ $0.1)$

Slika 4: Premiki vozlišč v mreži v smeri: a) $x$-osi in b) $y$-osi pri redukciji $\varepsilon=20 \%$ (zlitina 2024, $h_{0}=4 \mathrm{~mm}, 8 \mathrm{FE}, f=0,1$ ) 
form over the cross-section so that the differences between the surface and axis are apparent. The other trajectories between the surface and axis have the same shape and are distributed inside this area at mutually uniform distances. Area I ends near the vertical cross-section with the same displacements. Area II is observed after Area I inside the deformation zone. The same characteristics are visible, but the positions of the curves for the surface and axis are changed. Area III displays the same characteristics of the trajectories as Area I, but the inhomogeneity is lower. Area IV covers the exit from the roll gap, and the relationship of the values along the trajectories is same as in Area II. At the exit from the roll gap, the balance between the surface and axis is re-established.

The vertical displacements $\Delta y$ on the surface show a monotonic flow that follows the roll geometry in the roll gap. Because of the rolling symmetry, the vertical displacement on the axis is zero (Figure $\mathbf{4 b}$ ). The other trajectories have the same shape as the trajectories of the surface and are regularly distributed (the same distances on average).

The diagrams of the horizontal and vertical displacements shown in Figure 4 retain the characteristic shapes for all the tested conditions depending on the number of finite elements and the friction coefficient.

\subsubsection{Reduction of the strip thickness and indicators of deformation}

The reduction of thickness $\varepsilon_{\mathrm{h}}$ (often referred to as the deformation degree) in cold rolling is a particularly important, influential process parameter. The production processes for rolling aluminium and its alloys are predominantly carried out in an interval of $\varepsilon_{\mathrm{h}}=20-50 \%$. The same interval was used for the experimental rolling and simulation. The results obtained with the simulation also show that the thickness reduction significantly influences the components of deformation. In accordance with the goal of the work, the effective strain $\left(\varepsilon_{\mathrm{ef}}\right)$ was particularly singled out because the value and boundary states (yield stress, stresses and forces) primarily depend on $\varepsilon_{\text {ef }}$. Figure 5 presents FEM diagrams of the $\varepsilon_{\text {ef }}$ change along the deformation zone for a strip with the starting thickness of $4 \mathrm{~mm}$ that was rolled with reductions of 20 and $50 \%$.

The first reduction (Figure 5a) exhibits an obvious correlation with the diagrams of the $\Delta x$ displacements. The difference between the lengths of the trajectories on the surface and axis, conditioned by the shape of the deformation zone, causes large differences in the values of $\varepsilon_{\text {ef }}$ on these trajectories. Indeed, the same areas as for the $\Delta x$ displacements can be extracted from the diagram of $\varepsilon_{\text {ef }}$. However, the finite values of $\varepsilon_{e f}$ differ between the surface and axis, and thus the final strain over the crosssection of a strip is non-uniform. The strain relationships show that the deformation zone ends with a localisation of the plastic deformation in the surface layer. The localisation of the plastic deformation, i.e., the elastic area around the axis and the plastic area in the surface zone, causes phenomena that follow the inhomogeneous deformation of the vertical cross-section. One of these phenomena is the residual stress ${ }^{27}$.

The increase in the strip thickness reduction to $50 \%$ was followed by changes in $\varepsilon_{\text {ef }}$, so that an inhomogeneous deformation (differences between the values for the surface and axis) was formed at the entrance of the roll gap and retained along the entire deformation zone (Figure 5b).

\subsubsection{Relationships of the strip thickness and the effective strain}

Final values $\varphi_{\mathrm{h}}$ and $\varepsilon_{\text {ef }}$ for the trajectories of the surface and the axis, and the average values on the vertical cross-section of the strip with $h_{0}=4 \mathrm{~mm}$ were found (for the strips with $h_{0}=2 \mathrm{~mm}$ and $1.28 \mathrm{~mm}$ analogous results were obtained). Because $\varphi_{\mathrm{h}}$ and $\varepsilon_{\mathrm{ef}}$ are integral values, the differences between their values are apparent. The condition of plane strain obtained with the FEM simulation can be checked by comparing these two indicators of deformation. Specifically, for plane strain with components $\mathrm{d} \varepsilon_{1}, \mathrm{~d} \varepsilon_{2}$, and $\mathrm{d} \varepsilon_{3}$ and defined relationships $\mathrm{d} \varepsilon_{2}=0$ and $\mathrm{d} \varepsilon_{1} / \mathrm{d} \varepsilon_{3}=-1$, the following equation applies for
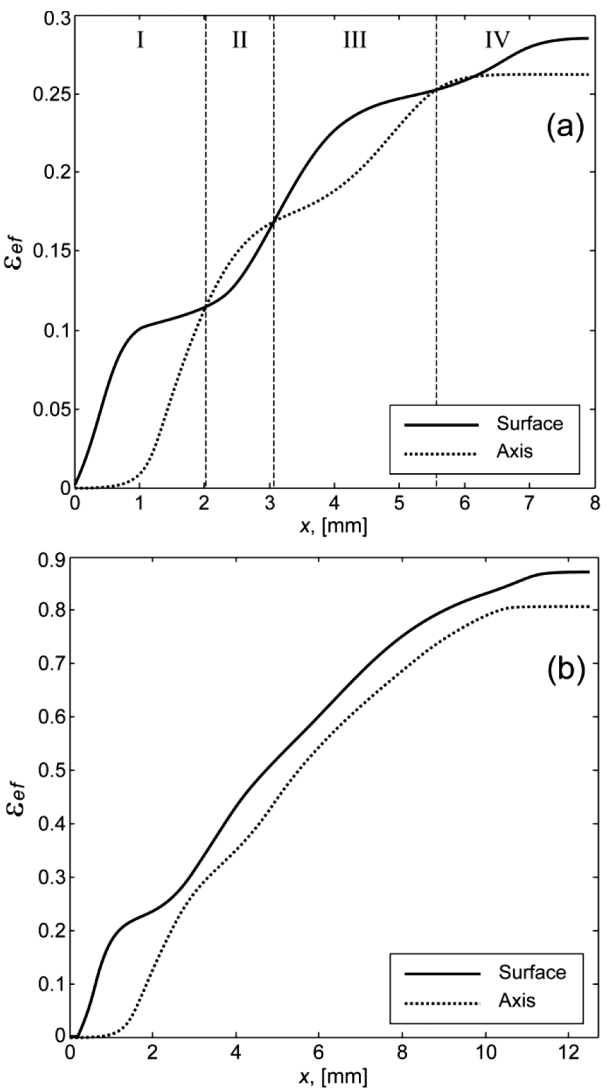

Figure 5: Effective strain on the surface and axis of a strip rolled with thickness reductions of: a) $20 \%$ and b) $50 \%$. Parameters of the simulation are as listed in Figure 4.

Slika 5: Efektivna napetost na površini in v osi traku, valjanega $\mathrm{z}$ redukcijo debeline: a) $20 \%$ in b) $50 \%$. Parametri simulacije so navedeni na sliki 4. 


\section{MIŠOVIĆ et al.: DEFORMATIONS AND VELOCITIES DURING THE COLD ROLLING OF ALUMINIUM ALLOYS}

the effective strain: $\mathrm{d} \varepsilon_{\mathrm{ef}}=(2 / \sqrt{3}) \mathrm{d} \varepsilon_{1}$, i.e., $\varepsilon_{\text {ef }}=1.155 \varepsilon_{1}{ }^{28}$ According to Equation (1) $\varepsilon_{1}=\varphi_{\mathrm{h}}$ and, therefore, the previous equation can be rewritten as follows:

$$
\begin{aligned}
\varepsilon_{\mathrm{ef}}= & 1.155 \varphi_{\mathrm{h}}, \varepsilon_{\mathrm{ef}} / \varphi_{\mathrm{h}}=1.155 \text { and } \\
& \left(\varepsilon_{\mathrm{e} 2} / \varphi_{\mathrm{h} 2}\right) /\left(\varepsilon_{\mathrm{ef} 1} / \varphi_{\mathrm{h} 1}\right)=1
\end{aligned}
$$

The values for relationships $\varphi_{\mathrm{h} 2} / \varphi_{\mathrm{h} 1}$ and $\varepsilon_{\mathrm{ef} 2} / \varepsilon_{\mathrm{ef} 1}$ slightly differ for the same rolling program. Therefore, the compatibility of the results obtained with the simulation using Equation (6) can be found with a sufficient accuracy. These results present an opportunity for a simple correlation of the change in the dimensions and the effective strain obtained with FEM.

The correlation of relationships $\varepsilon_{\mathrm{ef}} / \varphi_{\mathrm{h}}$ and the change in the dimensions were assessed. The change in $\varepsilon_{\mathrm{ef}} / \varphi_{\mathrm{h}}$ depending on the thickness reduction is similar for all the starting thicknesses. The area of change is limited, but all the values differ from 1.155. Therefore, the mean values of $\varepsilon_{\mathrm{ef}} / \varphi_{\mathrm{h}}$ for each initial thickness were calculated. The results were determined with a $95 \%$ confidence interval. The confidence interval in all the cases entirely covers the area of the changes in the values, indicating that the mean values can be reliably used.

It is obvious that the relationship $\varepsilon_{\mathrm{ef}} / \varphi_{\mathrm{h}}$ indicates a regular change on the surface and axis and that it depends on the starting thickness of the strip. Thus, the results of $\varepsilon_{\mathrm{ef}} / \varphi_{\mathrm{h}}=f\left(h_{0}\right)$ were analytically processed, and the equations used to approximate them were determined with a satisfactory accuracy. According to the limited number of data, the analytical processing of the results was completed using the STATEGRAPH program for all the equations checked with this software program package $^{29}$. The linear equations were chosen.

The derived equations of dependence $\varepsilon_{\mathrm{ef}} / \varphi_{\mathrm{h}}=f\left(h_{0}\right)$ were additionally checked for the cold rolling of the strips with starting thicknesses of $6,0.6$ and $0.012 \mathrm{~mm}$. The thickness of $6 \mathrm{~mm}$ is the largest starting thickness for cold rolling, $0.6 \mathrm{~mm}$ is the largest starting thickness for rolling thin strips, and $0.012 \mathrm{~mm}$ is the thickness for rolling the thinnest foils (aluminium foils with a thickness of $6 \mu \mathrm{m}$ are produced by doubling two $12-\mu \mathrm{m}$ foils prior to the rolling and separation after the rolling).
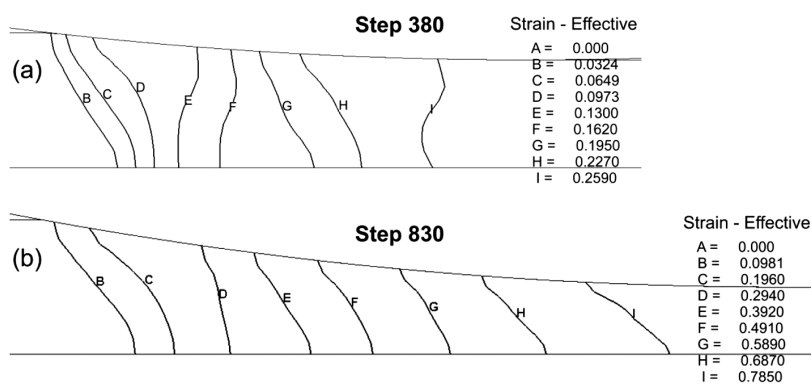

Figure 6: Isolines of $\varepsilon_{\text {ef }}$ for rolling a strip with a thickness of $4 \mathrm{~mm}$ with reductions of: a) $20 \%$ and b) $50 \%$ (simulation parameters as listed in Figure 4)

Slika 6: Izolinije $\varepsilon_{\text {ef }}$ pri valjanju $4 \mathrm{~mm}$ debelega traku, z redukcijo: a) $20 \%$ in b) $50 \%$. Parametri simulacije so navedeni na sliki 4.
The lowest value of the ratio $\varepsilon_{\mathrm{ef}} / \varphi_{\mathrm{h}}$ was obtained for the axis of a $12-\mu \mathrm{m}$ foil and it is 1.160 . This value also differs from the theoretical value of 1.155 , although only slightly. For the axis of the 6-mm strip, the difference is approximately $2 \%$, which represents an allowed deflection from the condition of proportionality for the plane strain. Therefore, the linear equations for the transition of the thickness reduction into effective strains depending on the starting thicknesses of the strips are quite reliable.

\subsubsection{Deformation zone}

The results in Figure 6 show the positions of the isolines for $\varepsilon_{\text {ef }}$ in the deformation zone during the rolling of a strip with a thickness of $4 \mathrm{~mm}$. The DEFORM program gives the possibility of presenting the deformation zone as isolines that divide the zone into eight intervals with a constant increment of $\varepsilon_{\mathrm{ef}} / 8$. The shapes of isolines as well as the areas between two consecutive isolines show a non-uniform deformation of the cross-section, and thus the theory of a homogeneous deformation over the
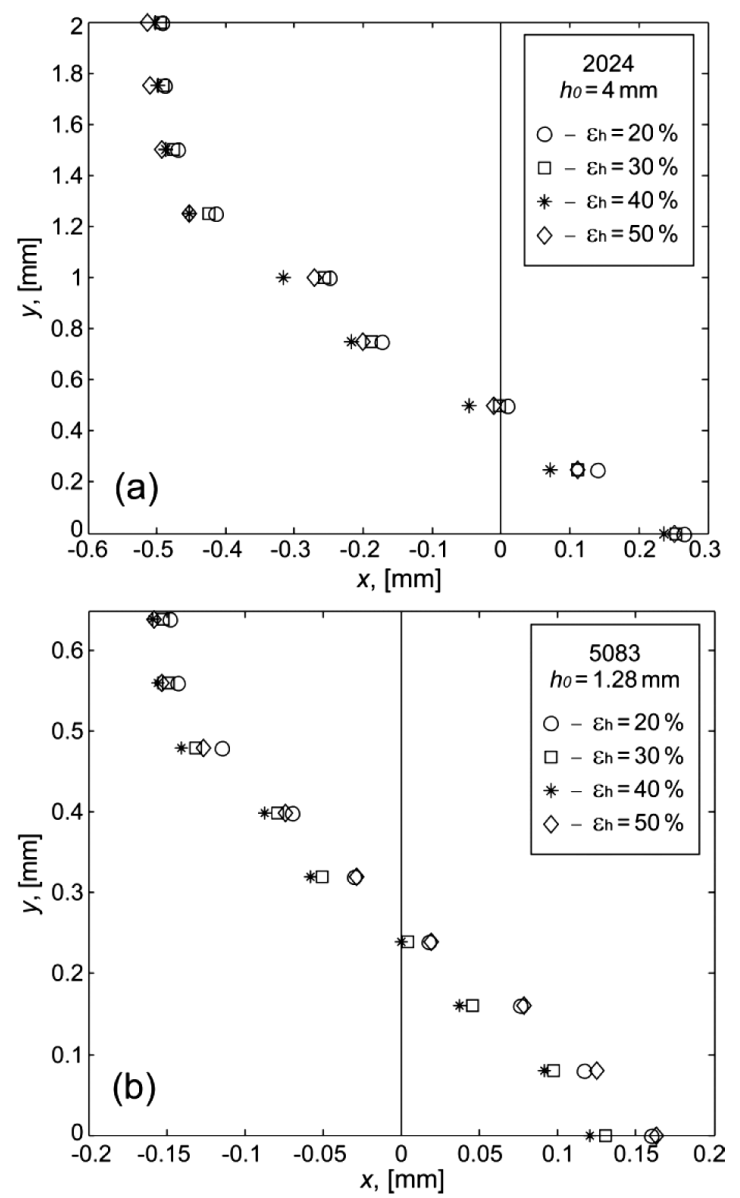

Figure 7: Isolines of the beginning of the plastic deformation zone $\left(\varepsilon_{\text {ef }}=0.002\right)$ for: a) alloy 2024 , strip with $h_{0}=4 \mathrm{~mm}$ and b) alloy 5083 , strip with $h_{0}=1.28 \mathrm{~mm}(y=h / 2$; simulation parameters as listed in Figure 4)

Slika 7: Izolinije začetka področja plastične deformacije $\left(\varepsilon_{\text {ef }}=0,002\right)$ za: a) zlitine 2024, trak $h_{0}=4 \mathrm{~mm}$ in b) zlitine 5083, trak debeline $h_{0}$ $=1,28 \mathrm{~mm}(y=h / 2$; parametri simulacije so navedeni na sliki 4) 
cross-section adopted for the conventional-rolling theory cannot be applied.

The positions of the isolines on the boundary of plasticity $\varepsilon_{\text {ef }}=0.002$ were chosen at the beginning. The results for the chosen conditions are given in Figure 7. The vertical line corresponding to the first point of the contact between the strip and the roll is presented as the " 0 " position at the start of the zone. The deformation on the cross-section begins non-uniformly (similarly to isoline B in Figure 6), first on the surface and prior to the initial contact of the strip and the rolls. This "out-ofcontact" deformation is a consequence of the strain gradient, which causes the pulling of the external region of the strip and has been known and considered in numerous works in the area of rolling ${ }^{21,25,30}$. It causes a significant difference between different reductions of the strip at the cross-section so that these cannot be reliably quantified.

The end of the deformation zone on the vertical cross-section is also non-homogeneous (isoline I in Figure 6). However, these lines represent the boundary of the plastic area of the complete vertical cross-section. A detailed examination showed that the plastic deformation continues (after isoline I) but it is localised on the
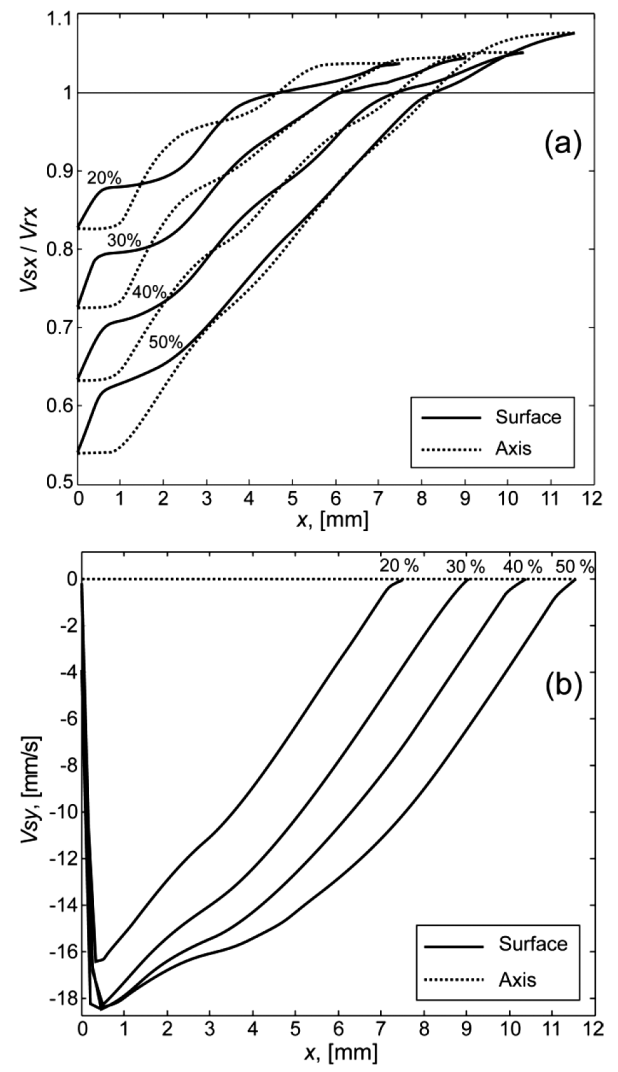

Figure 8: Diagrams of relationship changes of: a) $V_{\mathrm{s} x} / V_{\mathrm{r} x}$ and b) $V_{\mathrm{s} y}$ on the surface and on the axis along the deformation zone. Alloy 2024, $h_{0}=4 \mathrm{~mm}$, simulation parameters as listed in Figure 4.

Slika 8: Diagram sprememb odvisnosti: a) $V_{\mathrm{s} x} / V_{\mathrm{r} x}$ in b) $V_{\mathrm{s} y}$ na površini in vzdolž osi področja deformacije. Zlitina 2024, $h_{0}=4 \mathrm{~mm}$, parametri simulacije so navedeni na sliki 4. surface layer. Thus, the actual shape of the boundary of the plastic deformation is elastic-plastic (an approximate mirror image of the beginning of the plastic deformation). Such boundaries are completely in accordance with the experimental results ${ }^{28}$ and schemes used for the analysis of the process parameters (e.g., for use of "a slab analysis") $)^{31}$.

\subsection{Velocities}

The kinematics of cold rolling are determined by the velocities of the strip and roll in the deformation zone, i.e., by the horizontal $\left(V_{\mathrm{s} x}, V_{\mathrm{r} x}\right)$ and vertical $\left(V_{\mathrm{s} y}, V_{\mathrm{ry}}\right)$ velocities. In the conventional theory of rolling, the horizontal velocities are predominantly considered (Figure 1). Because they can be directly (immediately) measured, this situation offers an opportunity to include the control of the process in the results of the analysis.

In reality, no adequate data are available for the vertical velocity of strips for cold rolling in the conventional theory. The FEM simulation ensures that these data can also be obtained in the deformation zone.

\subsubsection{Horizontal velocity}

Figure 8a shows the relationship of the horizontal velocity of a strip and the velocity of the rolls $\left(V_{\mathrm{s} x} / V_{\mathrm{r} x}\right)$ for surface and axis trajectories. The velocity for a con-
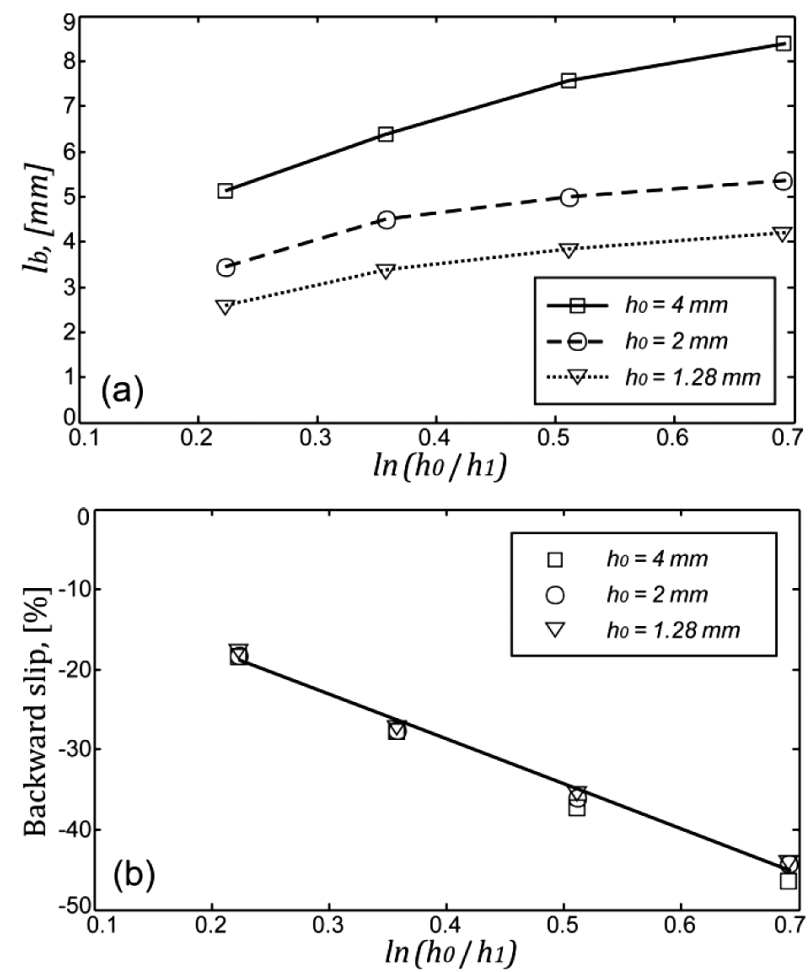

Figure 9: Results for the backward slip depending on the reduction degree obtained with the FEM simulation: a) length of the backwardslip zone and b) backward slip for the simulation parameters as listed in Figure 4

Slika 9: Rezultati za zaostajanje v odvisnosti od stopnje redukcije, dobljene s FEM-simulacijo: a) dolžina področja zaostajanja in b) zaostajanja za simulacijske parametre, navedene na sliki 4 
stant time interval $(\Delta \tau)$ is determined by the displacement itself $\left(V_{\mathrm{s} x}=\Delta x / \Delta \tau\right)$. As the roll velocity $\left(V_{\mathrm{r} x}\right)$ also changes slightly, it is expected that the diagrams for $V_{\mathrm{s} x} / V_{\mathrm{r} x}$ in Figure 8a completely correspond to the diagrams of the $\Delta x$ displacement shown in Figure $\mathbf{4 a}$.

Significant data for the backward slip are shown in Figure 9. The zone of the backward slip $\left(l_{\mathrm{b}}\right)$, i.e., its length, covers an important portion of the deformation zone and increases with an increase in the initial thickness and the degree of reduction (Figure 9a). The lowest $l_{\mathrm{b}} / l_{\mathrm{d}}$ relationship is $>2 / 3$ of the total deformation zone. The highest $l_{\mathrm{b}} / l_{\mathrm{d}}$ relationship is $>3 / 4$ of the total deformation zone, which means that for a neutral cross-section, $V_{\mathrm{s} x} / V_{\mathrm{r} x}=1$, it is necessary to obtain an adequate increment of the displacement and its homogenous distribution on the cross-section of the strip. Both of these factors require a certain length of the zone but also depend on the initial strip thickness and the reduction degree.

Diagrams of the backward slip depending on the initial strip thickness and reduction degree are shown in Figure 9b. A linear increase in the backward slip can be observed with an increase in the reduction degree and a slight difference in the tested strip thicknesses. As the shape of the backward-slip diagram is notably close to a straight line, the results are approximated using straightline equations. The scale for the backward slip expressed in percentages is convenient for the approximation. However, the results for relationship $V_{\mathrm{s} x} / V_{\mathrm{r} x}$ are selected for the equation because of a simple tracing of the values relative to the roll velocity and the connections with the forward slip. The derived equations are obtained and the correlation coefficients for the equations have high values. The other indicators also confirm their significance.

The diagrams of the backward slip and the free term in the equations of the $V_{\mathrm{s} x} / V_{\mathrm{r} x}$ relationship show that the backward slip is unavoidable (for $\varphi_{\mathrm{h}}=0 V_{\mathrm{s} x} / V_{\mathrm{r} x}>0$ ). In a physical sense, the condition for the unavoidable backward slip is completely justifiable, but it is not realistic that it differs from zero if the reduction is equal to zero. The equations should thus be accepted to show how the backward slip increases from zero to certain values, which are already in the area of small reduction degrees.

The forward slip changes in the interval of 2.4 to $12.5 \%$. According to the continuity equation, the forward slip has a significantly lower value than the backward slip (a smaller length of the zone causes a smaller total displacement).

The check of the simulation results for the backward and forward slips can be carried out on the basis of the continuity equation. All the results of the simulations satisfy this condition with a high level of accuracy. Therefore, the forward slip can be determined on the basis of the roll velocity, the backward slip and the reduction level.
The forward and backward slips were thoroughly tested and experimentally determined. Thus, the calculated values of the backward and forward slips provided in ${ }^{15}$ amount to 19.2 and $4.1 \%$, respectively. The results for the forward slip, which depends on the coefficient of friction, given $\mathrm{in}^{4}$ are 4 to $6 \%$. The forward slip depending on the velocity of the rolls and the reduction given $\mathrm{in}^{16}$ reaches up to $4 \%$, and $\mathrm{in}^{4,17}$ this value is as high as $10 \%$. All these results highly coincide with the results presented in this work.

\subsubsection{Vertical velocity}

The diagrams in Figure $\mathbf{8 b}$ show the change in the vertical velocity on the surface of a strip with a thickness of $4 \mathrm{~mm}$. These changes are characterised by the maximum values at the beginning of the deformation zone. The maximum value of velocity $V_{s y}$ is almost one order of magnitude lower than the horizontal velocity. The influence of this velocity on the total velocity/kinematics of rolling is thereby symbolic.

\section{CONCLUSIONS}

This paper presents the results and analysis of the deformations and kinematics during the cold rolling of aluminium alloy strips. The relevant experimental rolling was completed on a laboratory rolling stand using strips with thicknesses ranging from 4 to $1.28 \mathrm{~mm}$.

The FEM simulation of the process was completed using the DEFORM-2D program with a mesh of eight finite elements on a half thickness of a strip and a constant friction coefficient of $f=0.1$. The choice and analysis of deformations and velocities were carried out with the aim of comparison with the results from the conventional rolling theory. The following results were established:

The horizontal displacement diagram, presented with the chosen trajectories, has four characteristic areas with clear differences between the changes on the surface and axis. The shape of the changes is also reflected in the other strain components and velocities of cold rolling;

The relationship of the reduction degree and the effective strain based on the derived equations ensures a simple and reliable calculation of these indicators, through which other dependencies can also be quantified in the analysis of the rolling process;

With use of the FEM, the boundaries of the start and end of the deformation zone can be reliably identified as well as the out-of-contact deformation at the entrance and exit of the deformation zone;

The values of the backward slip amount to $18-46 \%$ and linearly depend on the strip thickness reduction. The forward slip lies in the interval of 2.4-12.5\% and can be quantified on the basis of the dependence of these two kinematic parameters of the cold-rolling process. 


\section{MIŠOVIĆ et al.: DEFORMATIONS AND VELOCITIES DURING THE COLD ROLLING OF ALUMINIUM ALLOYS}

\section{REFERENCES}

${ }^{1}$ P. Montmitonnet, P. Buessler, ISIJ International, 31 (1991), 525-538, doi:10.2355/isijinternational.31.525

${ }^{2}$ SIROLL ALU, Simens AG, Linz, 2012,1-28, available from World Wide Web: www.industry.siemens.com/verticals/metals-industry/en/ metals/aluminum-rolling/Pages/home.aspx

${ }^{3}$ I. Yarita, M. Katahama, K. Kenmochi, Kawasaki Steel Technical Report, 41 (1999), 20-24

${ }^{4}$ J. G. Lenard, Primer on Flat Rolling, 2nd ed., Elsevier, London 2014, doi:10.1016/B978-0-08-099418-5.00005-6

${ }^{5}$ X. Liu, J Iron Steel Res Int., 18 (2011) 1, 1-7, doi:10.1016/S1006706X(11)60001-0

${ }^{6}$ A. Kroll, A. Vollmer, ABB Review, 4 (2004), 44-49

${ }^{7}$ P. Hartley, C. E. N. Sturgess, C. Liu, G. W. Rowe, Int. Mater. Rev., 34 (1989), 19-34, doi:10.1179/imr.1989.34.1.19

${ }^{8}$ I. Y. A. Tarnovskii, A. A. Pozdeyev, V. B. Lyashkov, Deformation of Metals During Rolling, Pergamon Press, Oxford 2013, 200-259, doi:10.1016/B978-0-08-010223-8.50010-4

${ }^{9}$ H. Changqing, D. Hua, C. Jie, H. U. Xinghua, Y. Shuangcheng, Proc. Eng., 16 (2011), 745-754, doi:10.1016/j.proeng.2011.08.1150

${ }^{10}$ F. E. Dolzhenkov, Metall. Min. Ind., 1 (2009) 1, 33-37

${ }^{11}$ D. Pérez, F. J. Garcia-Fernandez, I. Diaz, A. A. Cuadrado, D. G. Ordonez, A. B. Diez, M. Dominguez, Eng. Appl. Artif. Intel., 26 (2013) 8, 1865-1871, doi:10.1016/j.engappai.2013.05.009

${ }^{12}$ S. Zhang, B. Song, X. Wang, D. Zhao, Appl Math Model, 38 (2014), 3485-3494, doi:10.1016/j.apm.2013.11.061

${ }^{13}$ R. Mei, L. Changsheng, X. Liu, Finite Elem Anal Des, 61 (2012), 44-49, doi:10.1016/j.finel.2012.06.006

${ }^{14}$ S. H. Zhang, G. L. Zhang, J. S. Liu, C. S. Li, R. B. Mei, Finite Elem Anal Des, 46 (2010), 1146-1154, doi:10.1016/j.finel.2010.08.005

${ }^{15}$ E. B. Li, A. K. Tieu, W. Y. D. Yuen, Opt Laser Eng, 39 (2003), 479-488, doi:10.1016/S0143-8166(02)00030-1
${ }^{16}$ E. B. Li, A. K. Tieu, W. Y. D. Yuen, J Mater Process Tech, 133 (2003), 348-352, doi:10.1016/S0924-0136(02)01049-X

${ }^{17}$ A. K. Tieu, Y. J. Liu, Tribol. Int., 37 (2004), 77-183, doi:10.1016/ S0301-679X(03)00048-3

${ }^{18}$ P. Hartley, I. Pillinger, C. Sturgerss, Numerical Modelling of Material Deformation Processes: Research, Development and Application, Springer-Verlag, London 1992, doi:10.1007/978-1-4471-1745-2

${ }^{19}$ J. Fluhrer, DEFORMTM 2D-User's Manual, Scientific Forming Technologies Corp., Ohio, 2004

${ }^{20}$ R. S. Prakash, P. M. Dixit, G. K. Lal, J Mater Process Tech, 52 (1995), 338-358, doi:10.1016/0924-0136(94)01728-J

${ }^{21}$ Y. M. Hwang, H. H. Hsu, J Mater Process Tech, 88 (1999), 97-104, doi:10.1016/S0924-0136(98)00390-2

${ }^{22}$ J. G. Lenard, S. Zhang, J Mater Process Tech, 72 (1997), 293-301, doi:10.1016/S0924-0136(97)00183-0

${ }^{23}$ Y. J. Liu, A. K. Tieu, D. D. Wang, W. Y. D. Yuen, J Mater Process Tech, 111 (2001), 142-145, doi:10.1016/S0924-0136(01)00541-6

${ }^{24}$ Aluminium Alloy-EN Standards for Rolled Aluminium, Aalco Metals Ltd, 2014, available from World Wide Web: www.aalco. co.uk/datasheets/Aluminium-Alloy-EN-Standards-for-Rolled-Alumi nium_51.ashx

${ }^{25}$ P. F. Thomson, J. H. Brown, Int J Mech Sci, 24 (1982), 559-576, doi:10.1016/0020-7403(82)90048-0

${ }^{26}$ A. B. Richelsen, V. Tvergaard, Int J Mech Sci, 46 (2004), 653-671, doi:10.1016/j.ijmecsci.2004.05.013

${ }^{27}$ N. Tadić, PhD Thesis, University of Montenegro, Podgorica, 2011

${ }^{28}$ W. A. Backofen, Deformation processing, Addison-Wesley Pub. Co., 1975

${ }^{29}$ STATGRAPHICS Centurion XVI - trial version, 2014, available from World Wide Web: www.statgraphics.com

${ }^{30}$ H. R. Le, M. P. F. Sutcliffe, Int J Mech Sci, 43 (2001), 1405-1419, doi:10.1016/S0020-7403(00)00092-8

${ }^{31}$ W. F. Hosford, R. M. Cadell, Metal Forming-Mechanics and Metallurgy, 4th ed., Cambridge University Press, Cambridge 2014 